اثر تنشهاى خشكى و شورى بر توليد هورمون IAA در باكترىهاى جداسازى شده از خاكىهاى

\author{
شور و شور-سديمى \\ رضا سليمانى، حسن توفيقى و حسينعلى عليخانى \\ دريافت:
}

كروه مهندسى علوم خاك، يرديس كشاورزى و منابع طبيعى، دانشكاه تهران، كرج

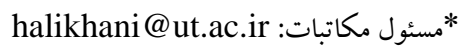

جكيده. اين تحقيق بهمنظور ارزيابى توانيى توليد هورمون Indole acetic acid (IAA) بهوسيلة باكترىهاى جداسازى شده از خاككهاى متأثر از خشكى و

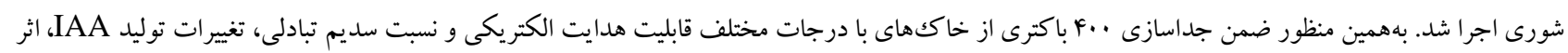

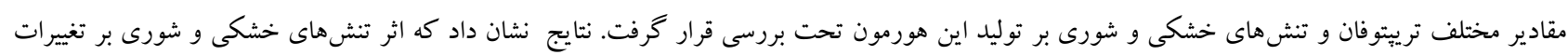

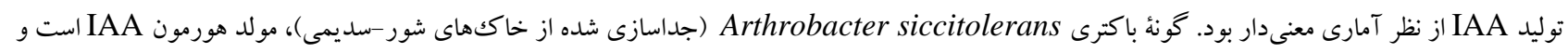

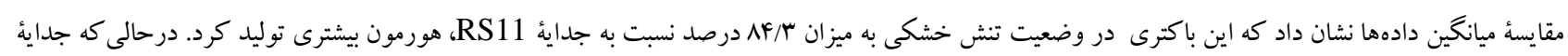

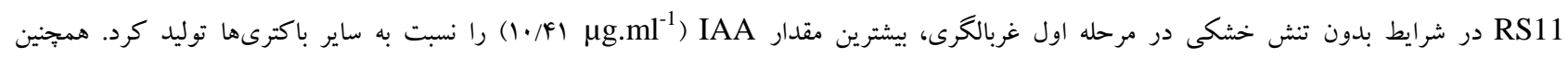
A. siccitolerans

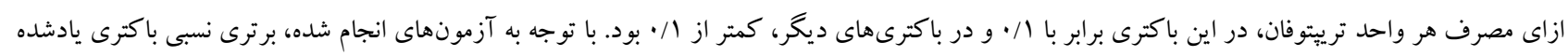

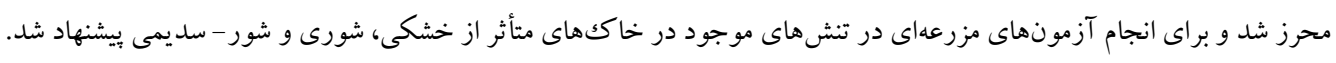

وازههاى كليدى. خشكى، نسبت جذب سطحى سديم، هدايتالكتريكى، هورمون IAA

\title{
The effect of drought and salinity tensions on IAA production in isolated bacteria from saline and saline-sodic soils
}

\author{
Reza Soleimani, Hasan Tofighi and Hosseinali Alikhani* \\ Received 09.12.2013 / Accepted 13.07.2015
}

\begin{abstract}
Department of Soil Sciences, College of Agriculture and Natural Resources, Tehran University, Karaj, Iran *Correspondent author: halikhani@ut.ac.ir
\end{abstract}

\begin{abstract}
This investigation was carried out to evaluate Indole acetic acid (IAA) production by isolated bacteria from drought and salinity affected soils. Four hundred bacteria were isolated from soils with different levels of electrical conductivity (EC) and sodium adsorption ratio (SAR). Then the ability of these bacteria to produce IAA and the effects of different amounts of tryptophan and drought-salinity tensions on IAA production were analyzed. Results indicated that the effects of drought and salinity tensions on variability of IAA production were statistically significant. One of the bacterial species isolated from saline-sodic soils, Arthrobacter siccitolerans, was IAA producer and data comparison indicated that under drought stress conditions it produced IAA $84.3 \%$ higher than isolate RS11. While isolated RS11 produced highest rate of IAA $\left(10.42 \mu \mathrm{g} \cdot \mathrm{ml}^{-1}\right)$ under normal conditions. Also, A.siccitolerans continued to produce IAA until the EC was $40 \mathrm{dS} . \mathrm{m}^{-1}$ and OP (Osmosis pressure) was -20 bar. The amount of IAA production per unit of applied tryptophan in this bacterium was 0.1 and in others it was lesser. According to experiments, the relative preference of this bacterium was verified and proposed for field experiments in drought, salinity and salinity-sodicity affected soils.
\end{abstract}

Keywords. drought, electrical conductivity, IAA, sodium adsorption ratio 
مونواكسـيزناز (Tryptophan-2-monooxigenase) راكــــ مى كند. اين آنزيم ترييتوفان را به IAM تبديل مئ كند. در مرحلة

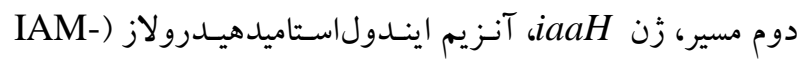
(hydrolase

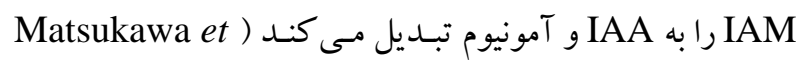

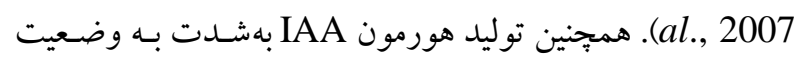

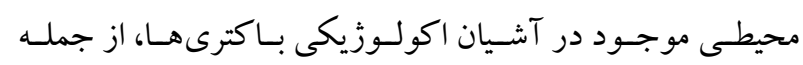
فاكتورهاى لازم براى فعاليت هاى ميكروبى شامل اسيدهاى آلى دوري،

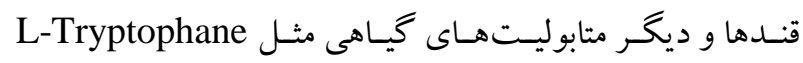

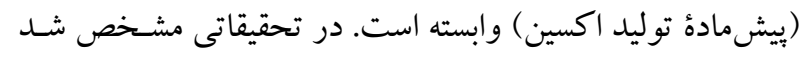
كه توان توليد اكسين توسط Pseudomonas putida با افزودن توني

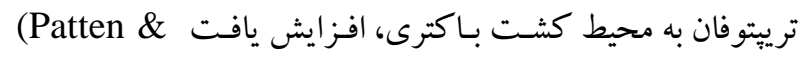

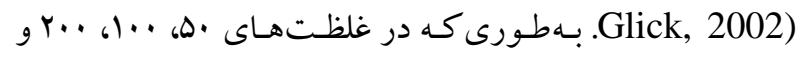

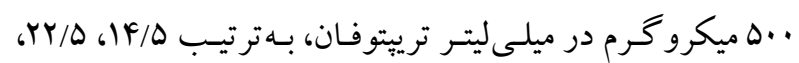

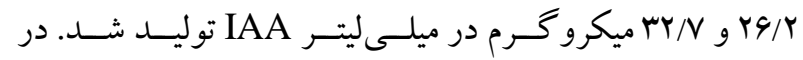

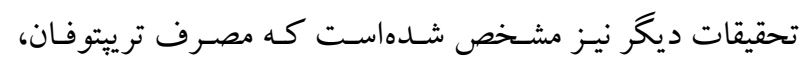
تو انايى توليـد هورمسون IAA را بـهوسيلة بـاكترى سـودوموناس

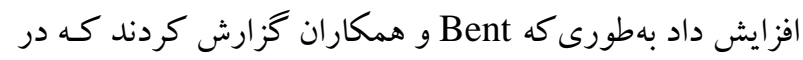

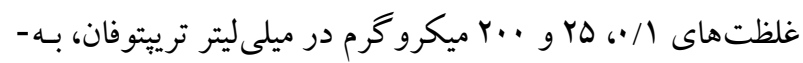

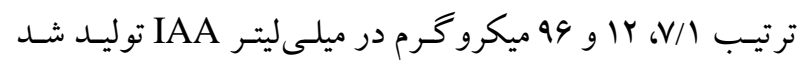
(Bent et al., 2001)

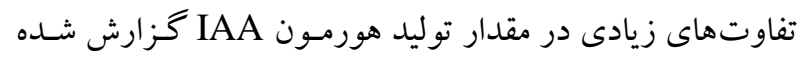

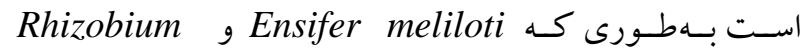

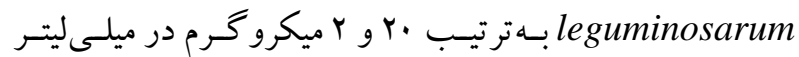
IAA توليد كردند (Dilfuza, 2011). تاكنون مطالعهاى درباب توان توليد هورمون IAA در باكترىهاى بومى در خاككهاى مناطق جنوبغ بربى كشور كه تحت تنش با درجات مختلف خشكى، شورى و شور-سديمى قرار دارند و همجنين باسخ هاى باكترى هاى مولد، به تنشهاى شورى و خشكى انجام نشدهاست. بنابراين تحقيق حاضر بهمنظور تعيين

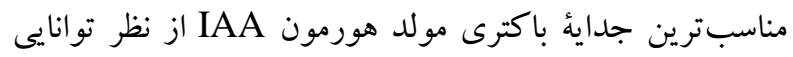
تحمل خشكى و شورى و كاراترين آن ازنظر مصرف ترييتوفان
يكى از مهم ترين آثار مستقيم بـاكترىهـاى محر كك رشـد گيـاه،

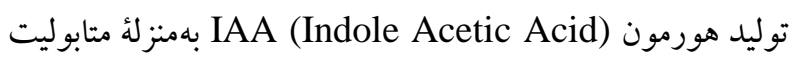

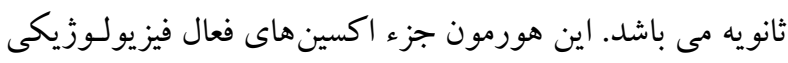
است. نقش اساسى اكسين، در القاء ريشهزايى و تشكيل آغازنـده

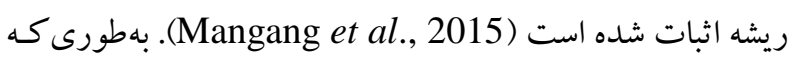

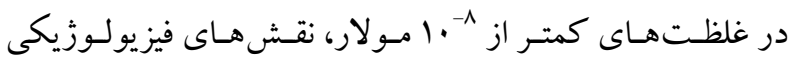

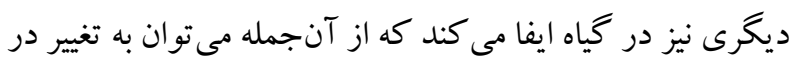

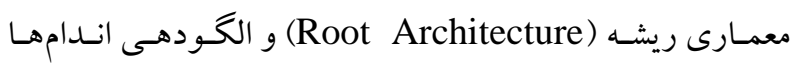
(Woodward et al., اشاره كرد (Organ Patterning) 2005; Lamine et al., 2008)

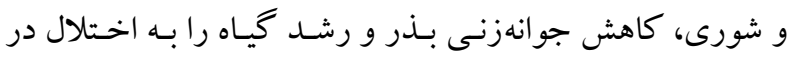
توليد هورمون IAA در گياه نسبت مىدهند (Dilfuza, 2011). بهورى كه مصرف IAA در غلظتهـاى كـم و بـه طور وييو سـته يشنهاد شده است (Fernandez-Falcon et al., 2005). توليد

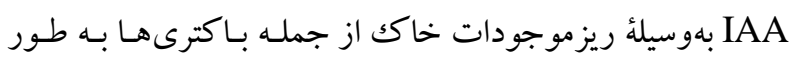

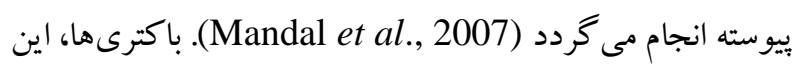

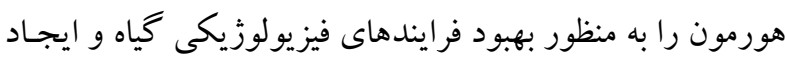

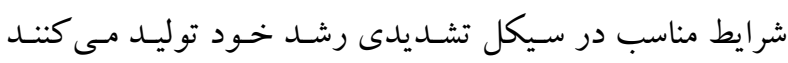
(Mohite, 2013). هورمون IAA توليد شده در اين باكترى ستهـا، با متعادل كردن توزيع اكسين در گياه، فرايندهاى رشد و نمو گياه

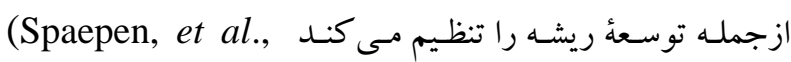

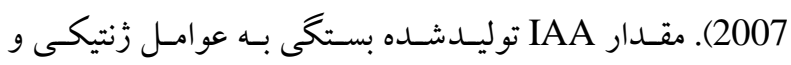

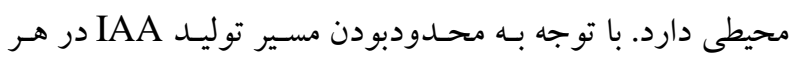

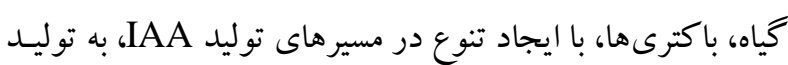

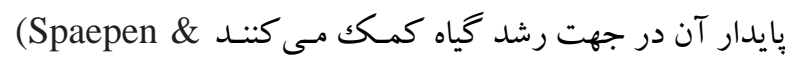
Vanderleyden, 2012) مسيرهاى اصلى بيوسنتز IAA شـامل

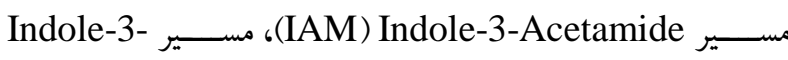

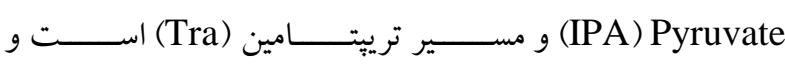
بيوسنتزهورمون IAA در باكترىها، بيشتر از مسير IAM و ماهى

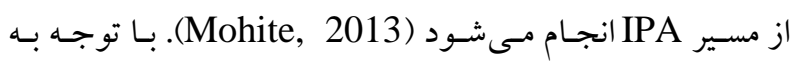

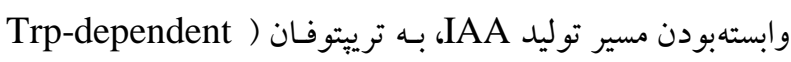

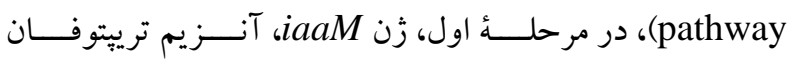


اسبكتروفتومتر سنجش شد؛ بهنحوى كه ابتدا باكترىها بـهمـدت

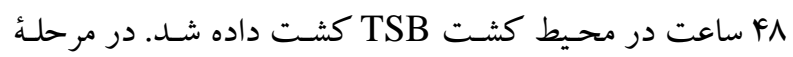
غربالخرى اوليه، •ه ميكروليتر از سوسبانسيون باكترى در مرحلد

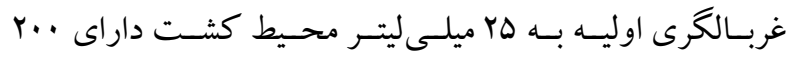

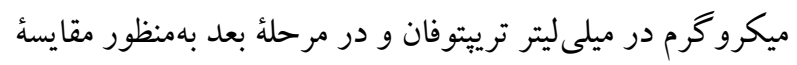

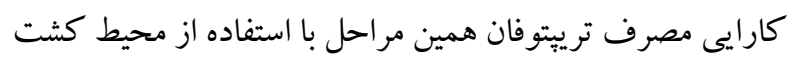

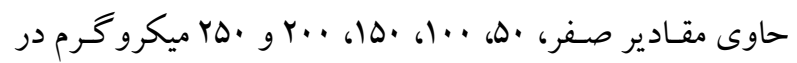
ميلى ليتر تريتوفـان انجـام شــ. بعـد از YF سـاعت، سوسيانسيون

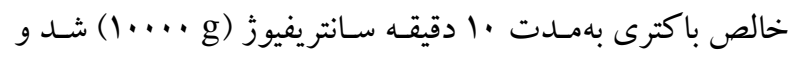
سلولهاى باكترى از محيط كشت و مـواد مترشحه جـدا شـدند.

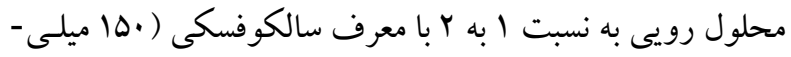

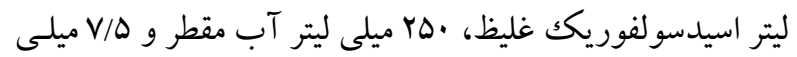

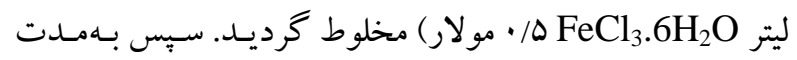

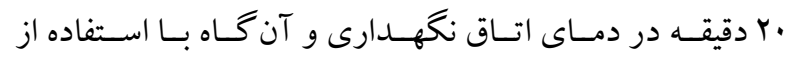
اســكتروفتومتر، مقــدار جـذب نـور در طـول مـوج هبه نـانومتر

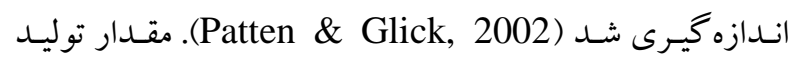
هورمون IAA با مقايسٔ جذب آن با جذب در نمودار استاندارد تهيه شده از ايندول|ستيككاسيد محاسبه شد.

\section{آزمون ميزان تحمل به تنش كم آبى باكترىها با استفاده از}

PEG-6000

بهمنظور ارزيابى ميزان تحمل جدايه در برابر سطوح مختلف

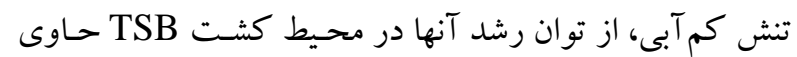

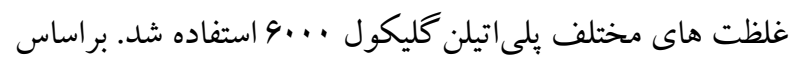
معادله (Michel \& Kaufmann, 1973) غلظت هـاى صفر،

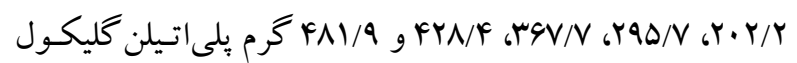

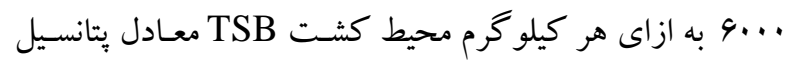

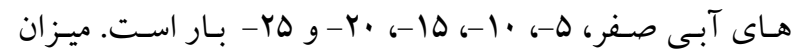

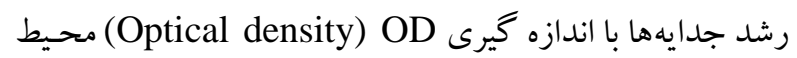

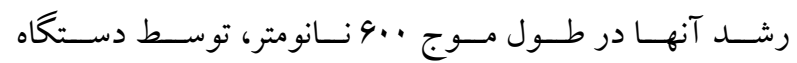
اسبكتروفتومتر تعيين و درصد كاهش رشد هر جدايه در سطوح مختلف بلى اتيلن كليكول در مقايسه با ميزان رشد همان جدايه در

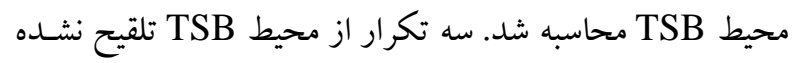

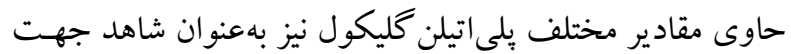

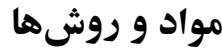

براى تهيئ نمونههاى خاك و جداسازى باكترىها از خاكك با استفاده از دستكاه موقعيتياب جهانى (GPS) و دستخاه سنج بر تابل، اقدام به مكانيابى و نمونهبردارى از توده خاكك هاى شور، شور-سديمى و معمولى و خاكك ريزوسفرى گياه گندم در

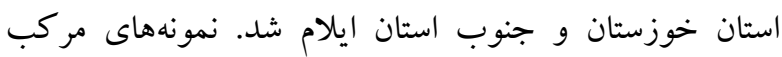

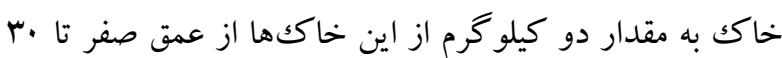
سانتى مترى تهيه شد و نمونهها بِ از هو ا خشك كردن بهمنظور

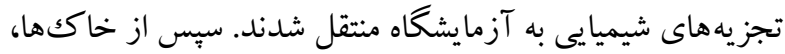

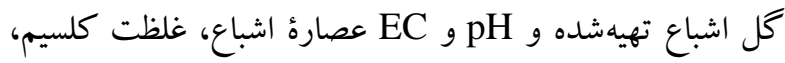
غلظت سديم و يتاسيم به روش فليم فتومترى اندازه گيرى شدند Sodium (Page et al., 1982) Adsorption Ratio

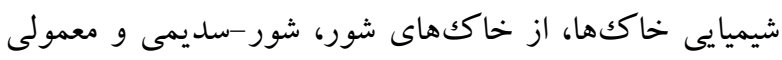

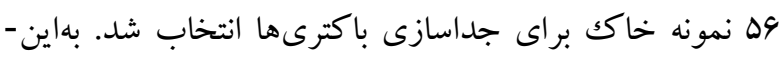

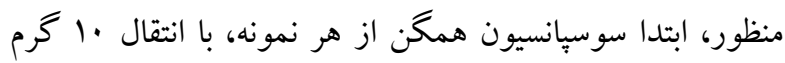

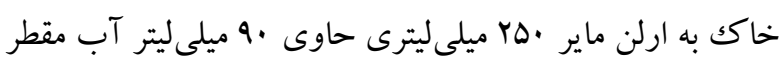

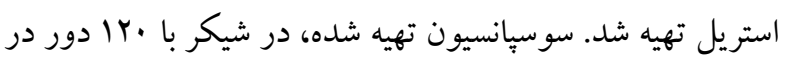

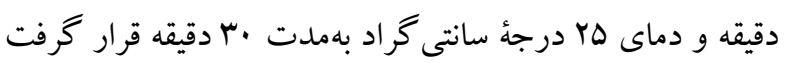

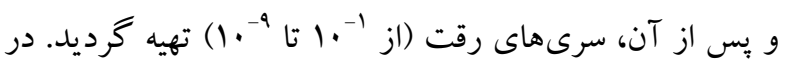
نهايت، // ميلى ليتر از هر رقت، بر روى پيليت حاوى محيط

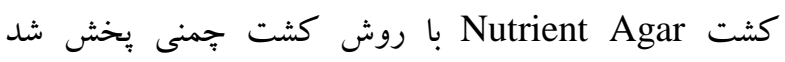
(Wang et al., 2007)

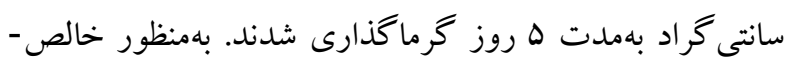

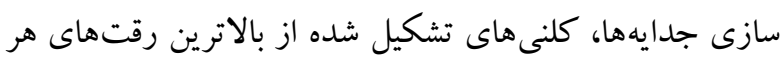

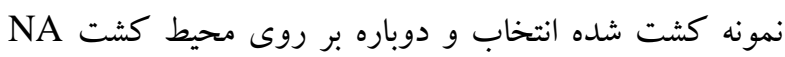
رشد داده شدند. كلونىهايى كه پِ از كشتهاى متوالى مشابهت داشتند انتخاب شده و براى استفادة بعدى روى محيط كشت شيبدار در يخجال نخهدارى شدند.

ارزيابى جدايههاى باكترى از نظر توان توليد هورمون

IAA

توانيى توليد هورمون IAA با روش ييشنهادى Bric انجام شـد. براى اندازه گيرى كمى توليد IAA در محيط كشت مايع، شدت

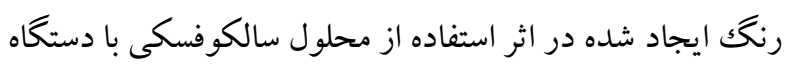


در ميلى ليتر، تنش خشكى در شش سطح شامل صفر، ه-، . [--،

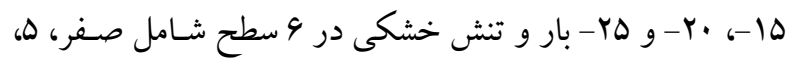

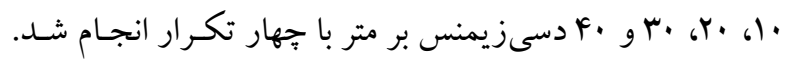

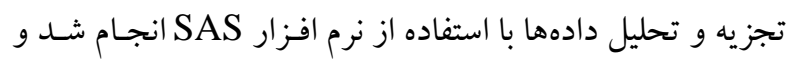

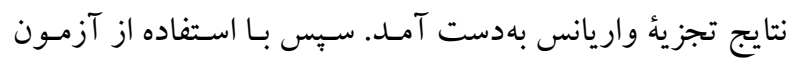

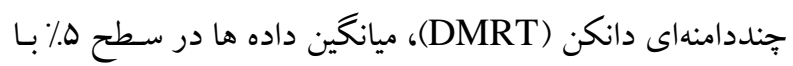

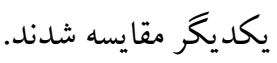

\section{نتايج و بحث}

نتايج تجزئ شيميايى خاككهاى نمونهبردارى شده نشان داد كه

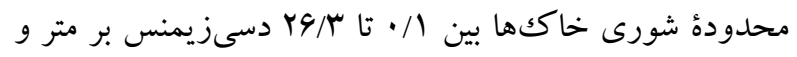

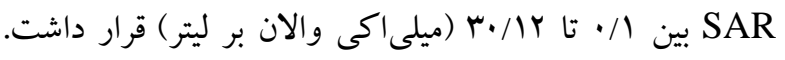

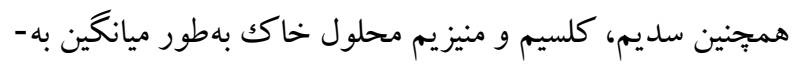

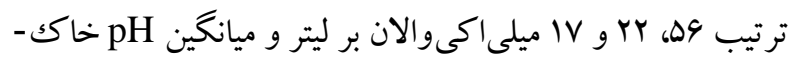

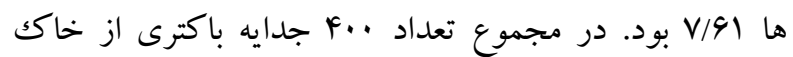
ريزوسفرى و غير ريزوسفرى جداسازى گرديد.

\section{فراوانى مقادير توليد هورمون IAA توسط جدايههاى باكترى}

فراوانى مقادير توليد هورمون IAA در محدودههاى با فاصله هاى ه/ ميكرو گرم در ميلىليترى در شكل ا نشان داده شده است. همانطور كه مشاهده مىشود، مقادير بالاى توليد هورمون

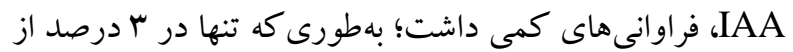

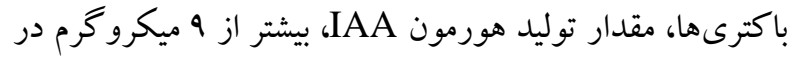

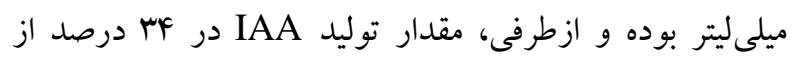

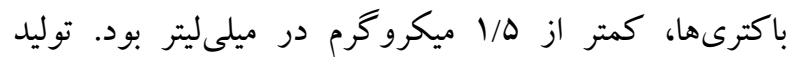

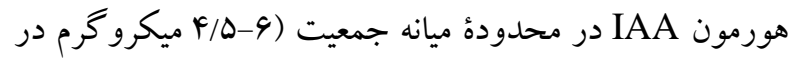

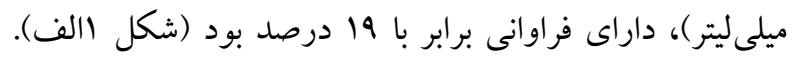

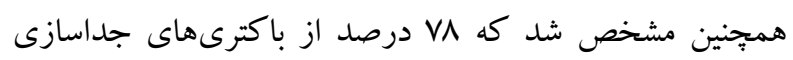

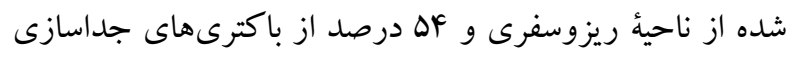

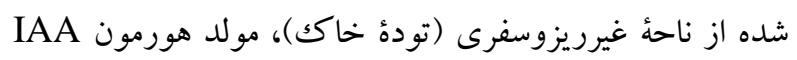

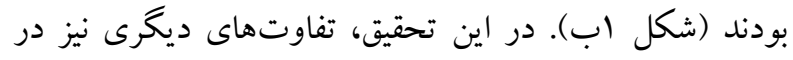

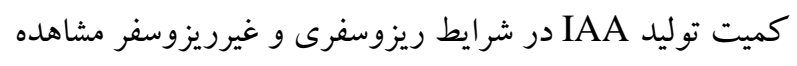
شد (شكل اج). بهطورى كه بيشترين فراوانى توليد هورمون
تعيـين ميـزان OD ايسن محــيط در وضـعيت فــوق تهيـه شـــ

.(Sandhya et al., 2009)

\section{آزمون ميزان تحمل در برابر تنش شورى}

بهاين منظور، توان رشد جدايههـاى مختلف بـاكترى در محيط

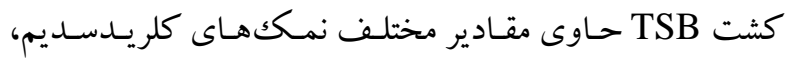
كلريدكلسيم و كلريدمنيزيم تحت ارزيابى قرار كرفـت. مقـادير نمكك اضافه شده بهنحوى تنظيم شد كه نتيجه آن، ايجاد شورى -

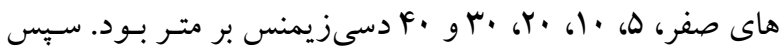
تغييرات رشد جدايهها با اندازه گيرى OD محيط رشـد آنها در

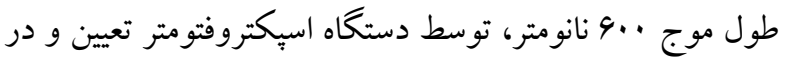
بين جدايهها با هم مقايسه شد.

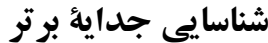

براى شناسايى باكترىهاى برتر به روش زنتيكى (16S rRNA)،

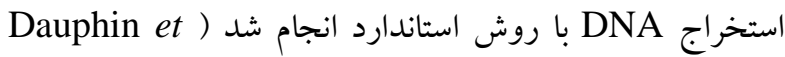
كاب (al., 2009 ابتدا ليز سلول و تغيير ماهيت دادن بروتئين با با بهكار گيرى بافر ليزكنده (ليزوزيم، SDS EDTA، بروتئيناز K )، صورت گرفت و سيس با استفاده از فنل و كلروفرم تمام اجزاى غير از اسيدهاى نو كلئيك رسوب داده شد ( Maciel et

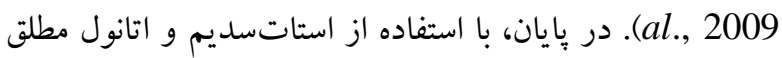

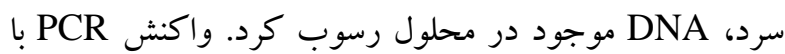
استفاده از دستگاه ترموسايكلر (PCR) با شرايط تكثير استاندارد انجام شد. در اين تحقيق، براى تكثير زن 16S rDNA جدائ

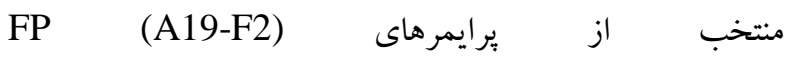
, (5'AGAGTTTGATCCTGGCTCAG3') RP(A1R1)(5'AAGGAGGTGATCCAGCCGCA3' (3'3 استفاده شد (Lorraine, et al., 2000). محصول بهدستآمده از PCR در زل آكارز ا درصد، بار گذارى و بعد از

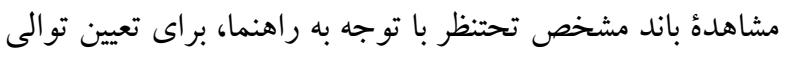
به شركت ماكروزن كرهٔ جنوبى ارسال شد. تجزيههاى آمارى آزمايشات در قالب طرح كـاملاً تصـادفى، تيمـار ترييتوفـان در

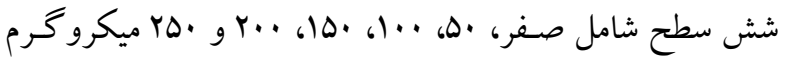


ريزوسفرى در سطح يككدرصد معنىدار بود (جدول ()).

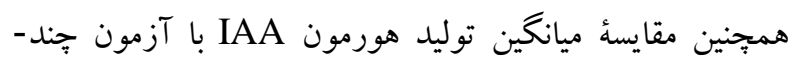
دامنهاى دانكن در سطح ه درصد نشان داد كه در بين باكترى - مهن

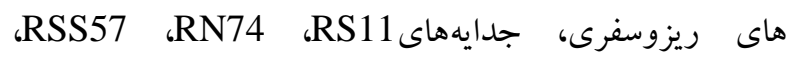

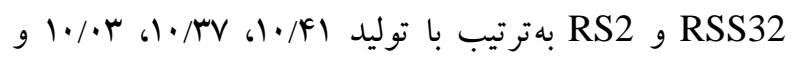
1.1 ميكرو كرم در ميلىليتر بيشترين مقدار توليد هورمون

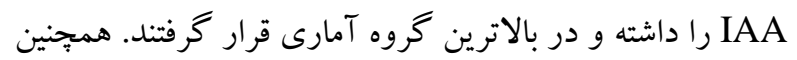

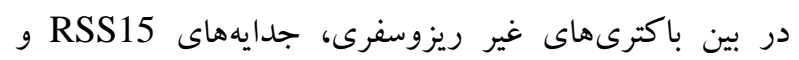

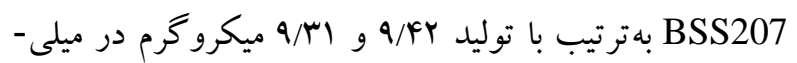
ليتر بيشترين مقدار توليد هورمون IAA را داشتند و در بالاترين

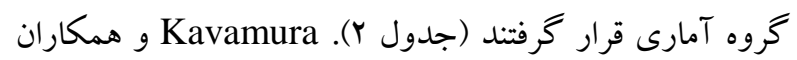

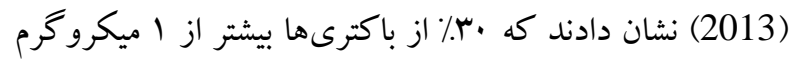

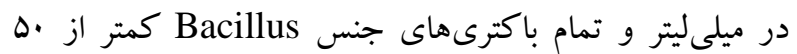
ميكرو گرم در ميلى ليتر هورمون IAA توليد كردند.

9-V/D در باكترىهاى ريزوسفرى، مربوط به محدودة IAA

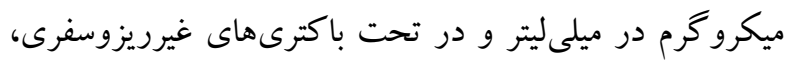

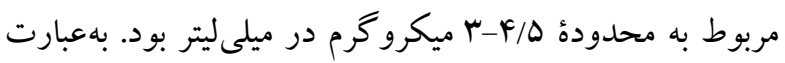

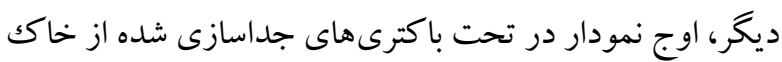
ريزوسفرى به سمت مقادير بيشينه و در تحت باكترىهاى جداسازى شده از خاكك غير ريزوسفرى به سمت مقادير كمينه

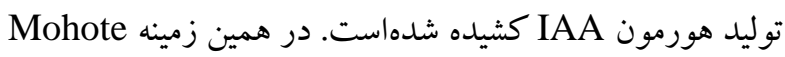

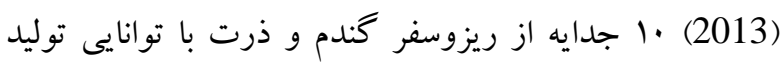

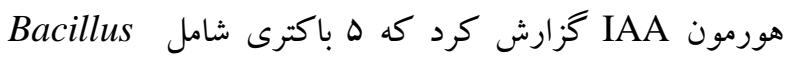
B. ‘Lactobacillus acidophilus ‘megaterium و B. cereus ،subtilis

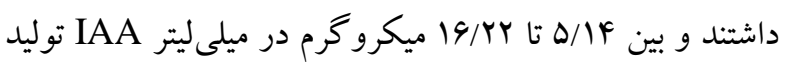
كردند.

تغييرات توليد هورمون IAA نتايج تجزئ واريانس دادها نشان داد كه تفاوتهاى بين توليد هورمون IAA در جدايههاى باكترى ريزوسفرى و غير -
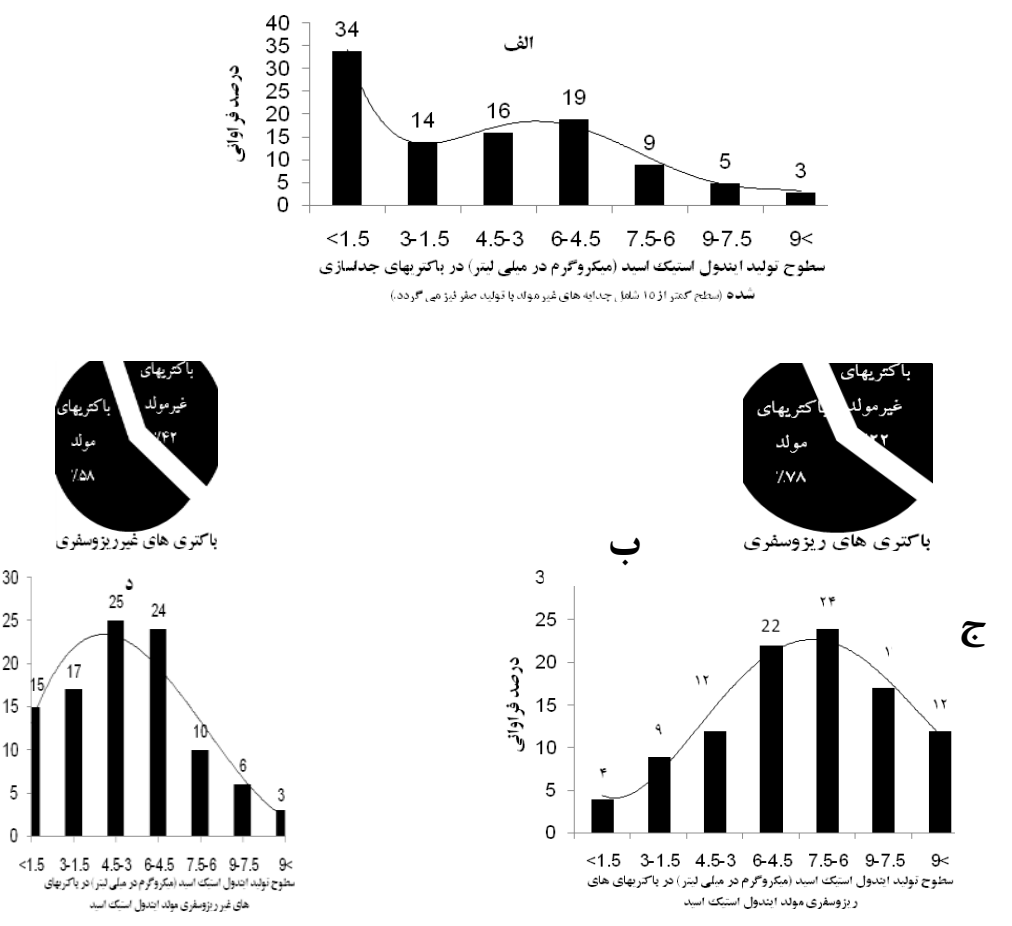

شكل ا-مقايسٔ فراوانى توليد هورمون IAA در جدايه هاى باكترى تحت مطالعه. الف-فراونى توليد در جدايههاى باكترى؛ ب-نسبت باكترىهاى مولد و غير مولد؛

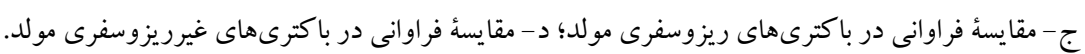

Fig. 1. Comparison of IAA production frequency in isolated bacteria. 
جدول ا- خلاصهُ نتايج تجزئُ واريانس (ميانگين مربعات) توليد هورمون IAA توسط جدايههاى ريزوسفرى و غير ريزوسفرى.

Table 1. Results of variance analysis (mean squares) of IAA production by rhizospheric and non-rhizospheric bacteria.

\begin{tabular}{|c|c|c|c|}
\hline احتمال & ميانكين مربعات & درجة آزادى & منبع تغيير \\
\hline \multicolumn{4}{|c|}{ جدايههاى ريزوسفرى } \\
\hline . MFr & $F / r)^{\text {ns }}$ & r & 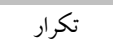 \\
\hline.$/ .14$ & $r F \Delta / 9^{*}$ & $\wedge 9$ & توليد IAA \\
\hline & YF/Y & iva & خطا \\
\hline
\end{tabular}

\begin{tabular}{|c|c|c|c|}
\hline & & & $\mathrm{CV} \%=\Lambda / F r$ \\
\hline \multicolumn{4}{|c|}{ جدايههاى غير ريزوسفرى } \\
\hline$\cdot / \mathrm{FVI}$ & $\Lambda N \Delta^{\mathrm{ns}}$ & r & ت تكرار \\
\hline \multirow[t]{3}{*}{ •/rY } & $9 \Delta 9 / F^{*}$ & $r .9$ & توليد IAA \\
\hline & $\Delta r / 9$ & 911 & خطا \\
\hline & & & $\mathrm{CV} \%=9 / \mathrm{r}$ \\
\hline
\end{tabular}

"* نشاندهندة معنى داربودن در سطح ه درصد مى باشد

جدول r- مقادير هورمون IAA توليدشده توسط جدايههاى باكترى برتر ريزوسفرى و غير ريزوسفرى.

Table 2. Amounts of IAA produced by upper rhizospheric and non-rhizospheric isolated bacteria

\begin{tabular}{|c|c|c|c|c|c|c|c|c|}
\hline \multicolumn{2}{|c|}{ شيب منحنى تحمل به تنش } & \multirow{2}{*}{ 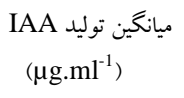 } & \multirow[b]{2}{*}{ جدايههاى غير ريزوسفرى } & \multirow[b]{2}{*}{ رديف } & \multicolumn{2}{|c|}{ شيب منحنى تحمل به تنش } & \multirow{2}{*}{$\begin{array}{l}\text { IAA ميانكين توليد } \\
\left(\mu \mathrm{g} . \mathrm{ml}^{-1}\right)\end{array}$} & \multirow{2}{*}{ ريزوسفرى } \\
\hline 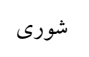 & 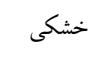 & & & & 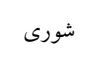 & خشكى & & \\
\hline$-\cdot / 11 \wedge b$ & $-\cdot / 1 \vee q c$ & $9 / \propto r a$ & BS153 & 1 & $-\cdot /$ rFe & $-\cdot / / V \cdot c$ & $1 . / 41 \mathrm{a}$ & RS11 \\
\hline$-\cdot / / \mathrm{rrc}$ &.$- / 191 \mathrm{c}$ & $9 / \Gamma / a$ & BSS207 & r & $-\cdot / I r A c$ & $-\cdot / / 9 \mathrm{rc}$ & $1 . / \mathrm{ra}$ & RN74 \\
\hline$-\cdot / 1 \cdot f b$ & $-\cdot /$ VVAC & $9 / \mathrm{rVb}$ & BS80 & $r$ & $-.1 .9 \mathrm{ra}$ & $-\cdot /$ r^a & $1 . / . \mathrm{ra}$ & RSS57 \\
\hline$-\cdot / 1 \cdot \wedge b$ & $-\cdot / 199 \mathrm{c}$ & $9 / / v b$ & BSS174 & r & $-\cdot / 1 \cdot 9 b$ & $-\cdot / / \Lambda \mathrm{fc}$ & $1 . / 1 \mathrm{a}$ & RSS32 \\
\hline$-\cdot / 1 \mathrm{rgc}$ & $-\cdot / / v i d$ & $\mathrm{Q} / \mathrm{rb}$ & BN276 & $\Delta$ & $-\cdot / 10 \wedge d$ & $-\cdot / 1 M M C$ & $1 \cdot 1 \cdot \mathrm{a}$ & RS2 \\
\hline$-\cdot / 1 \cdot 1 b$ &.$- / 199 \mathrm{c}$ & N/YAC & BSS179 & 4 & $-\cdot / 1 \cdot r b$ & $-\cdot / 199 c$ & $9 / v 9 b$ & RN76 \\
\hline$-\cdot / 11 \Delta \mathrm{b}$ & $-\cdot / 1 \Delta \mathrm{vb}$ & N/Irc & BSS172 & $v$ & $-\cdot /$ Irrc & $-\cdot / 199 \mathrm{fc}$ & $a / v \Delta b$ & $\mathrm{RN} 83$ \\
\hline$-\cdot / / \mathrm{rac}$ & $-\cdot / M M C$ & $\Lambda \cdot 1 \mathrm{c}$ & BSS234 & $\wedge$ & $-\cdot / 11 \wedge b$ & $-\cdot / r i r d$ & $a / r r b$ & RN80 \\
\hline$-\cdot /$ TrFe &.$- / 194 \mathrm{c}$ & V/DFC & BS96 & 9 &.$- / .91 \mathrm{a}$ & $-\cdot / 10 \mathrm{vb}$ & $\Lambda / V F C$ & RN65 \\
\hline.$- / .9 \wedge \mathrm{a}$ & $-\cdot / 1 r q a$ & $9 N r d$ & BSS192 & 1. & $-\cdot / 1 \cdot \wedge b$ & $-\cdot / /$ rva & N/VIC & RS10 \\
\hline
\end{tabular}

R=Rhizosphere, B=Bulck, S=Saline, $S S=$ Saline- sodic, $N=$ =Non-saline soils

باكترى به تنش ايجاد شده است. بهطورى كه شيب كاهشى كمتر (شيب ملايم تر)، نشان دهندهُ تحمل نسبى بيشتر است كه دربارة

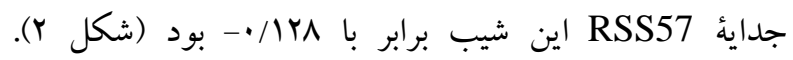

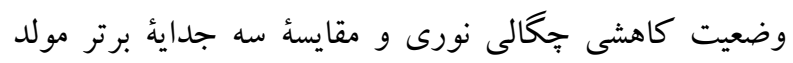
هورمون IAA در شكل r نشان داده شده است. همانطور كه در جدول r نشان دادشدهاست، جداية RSS57 نسبت به جدايه هاى ديخر داراى توان تحمل به خشكى بيشترى بود و يس از آن،

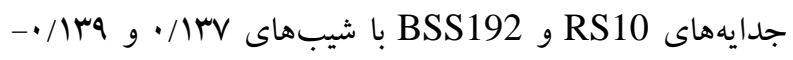
در رتبه هاى بعدى قرار گر فتند.

\section{مقايسة توان تحمل تنش به خشكى و شورى}

در باب سنجش تنش خشكى، با حل كردن مقادير مختلف ماده PEG 6000 در محيط كشت باكترى، قابليت استفاده مورلكولهاى آب كاهشيافته و يتانسيلهاى اسمزى متفاوتى ايجاد شد. همانطور كه در شكل r در باب جدائ RSS57 مشاهده مى كردد، با افزايش غلظت PEG 6000 در محيط كشت، جِّالى نورى (OD600) به عنوان معيارى از رشد باكترى روند كاهشى نشان داد. شيب منحنى حاصل، نشاندهندهُ شدت باسخ جدائ 

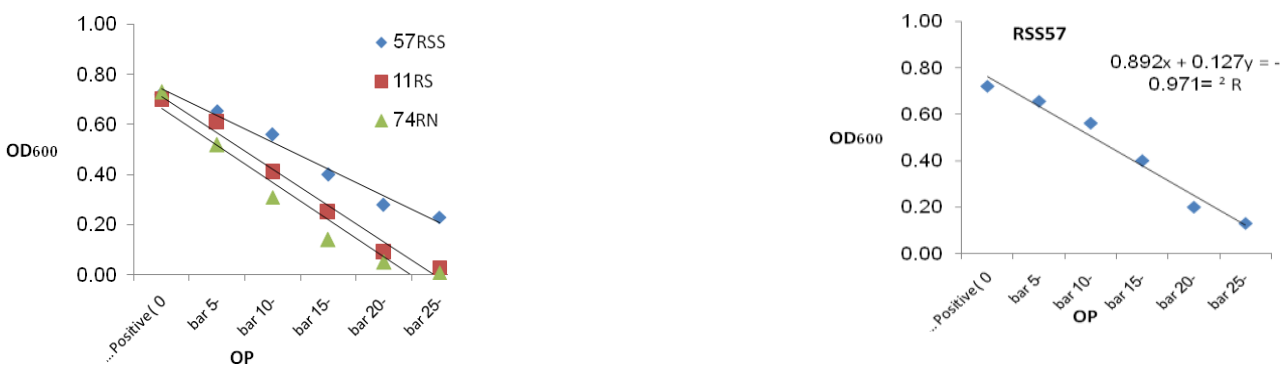

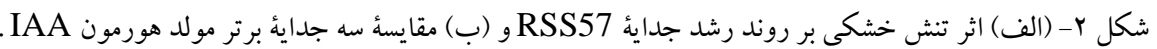

Fig. 2. The impact of drought tension on A) growth trend of RSS57 isolate and B) comparison of three high IAA producers. $\mathrm{OP}=$ Osmosis potential.

اثر مصرف تريّوفان در سطوح مختلف تنش خشكى بر

توليد هورمون IAA

نتايج تجزئُ واريانس نشان داد كه تأثير غلظتهاى مختلف ترييتوفان، تنش خشكى و برهم كنش آنها بر مقدار توليد هورمون IAA بهترتيب در سطح يك و ينج درصد معنىدار بود

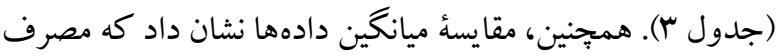
ترييتوفان در تحت جدائ RSS57 باعث توليد هورمون IAA 0. ميشترى نسبت به ساير جدايها شد. اين جدايه، در غلظت ميكرو گرم در ميلىليتر ترييتوفان، مقدار ب/Y F ميكرو ميلىليتر هورمون IAA توليد كرد كه نسبت به توليد هورمون IAA א N د درصد افزايش نشان داد. درحالى كه جدائ RS11، در وضعيت بدون تنش خشكى در مرحلهُ اول غربال گرى، بيشترين

$$
\text { مقدار IAA را توليد كرد (جدول Y). }
$$

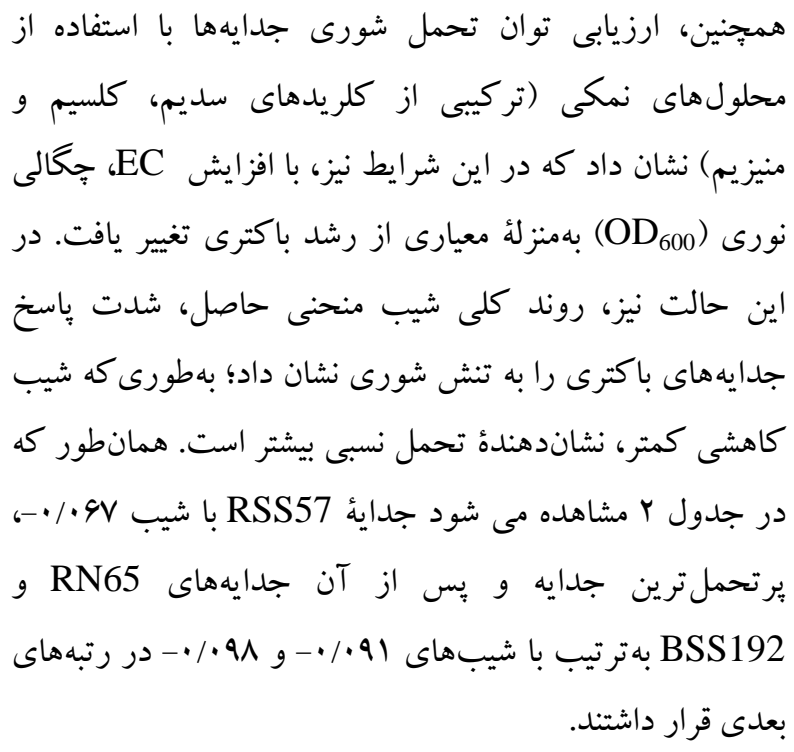

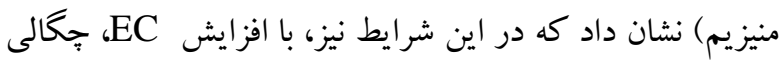
نورى (OD600) بهمنزله معيارى از رشد باكترى تغيير يافت. در اين حالت نيز، روند كلى شيب منحنى حاصل، شدت ياسخ جدايه هاى باكترى را به تنش شورى نشان داد؛ بهطورى كه شيب كاهشى كمتر، نشاندهنده تحمل نسبى بيشتر است. همانطور كه در جدول r مشاهده مى شود جدائ RSS57 با شيب 9V •.-6، يرتحملترين جدايه و پيس از آن جدايههاى RN65 و

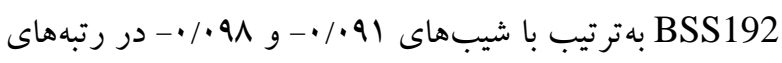
بعدى قرار داشتند. جدول ب- خلاصه نتايج تجزيةٌ واريانس (ميانخين مربعات) تغييرات توليد هورمون IAA متأثر از مصرف ترييتوفان و سطوح تنش خشكى. *** و *ه ترتيب نشاندهندة معنى داربودن در سطوح او ها درصد مى باشد.

Table 3. Results of variance analysis (mean square) of IAA production variation as affected by tryptophan application and drought tension levels.

\begin{tabular}{|c|c|c|c|}
\hline احتمال & ميانكين مربعات & درجة آزادى & منبع تغيير \\
\hline - / FAY & $\mid F / \mu Y^{n s}$ & $r$ & تكرار \\
\hline$\% r$ & $\mathrm{FVG/T**}$ & 9 & جدايه باكترى \\
\hline - & $19 Y / V^{*}$ & $\Delta$ & مصرف ترييتوفان \\
\hline.$/ 11$ & $r V F / \Delta *$ & $\Delta$ & تنش خشكى \\
\hline$\cdot / \mu F$ & $\Delta V G / Y^{*}$ & ro & جدايه*تريتوفان \\
\hline.$/ r^{4}$ & $G M F / N^{*}$ & ra & جدايه*تنش خشكى \\
\hline.$/ . \mathrm{IV}$ & rrq/9* & ro & ترييتوفان*تنش خشكى \\
\hline \multirow[t]{2}{*}{$. / \cdot+1$} & १४r/N* & rro & جدايه *ترييتوفان*تنش خشكى \\
\hline & $r E / r$ & 1.0 & خطا \\
\hline
\end{tabular}


1. ترييتوفان (يكك ميكرو گرم در ليتر) توليد كردند كه بيانگر

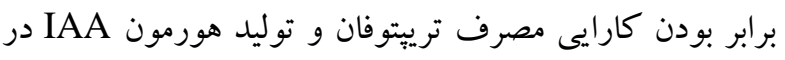

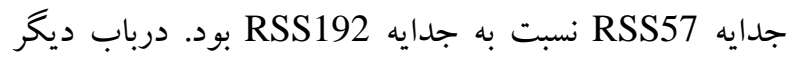

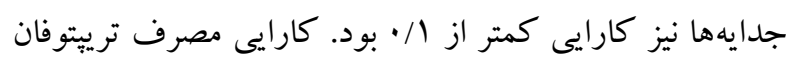

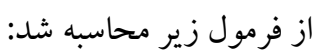

$\mathrm{E}_{\mathrm{t}}=\left(\mathrm{P}_{\mathrm{t}}-\mathrm{P}_{\mathrm{c}}\right) / \operatorname{Tr} \mathrm{p}_{\mathrm{app}}$

Eو مصرف تريبتوفان

Pو

Trp
در ديخر تيمارهاى مصرف ترييتوفان نيز اين روند ملاحظه شد؛ بهورى كه در غلظت . . . ميكرو گرم در ميلى ليتر ترييتوفان نيز،

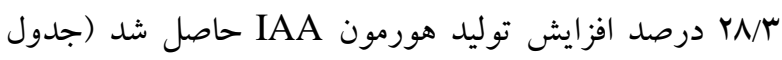

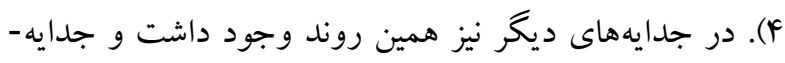

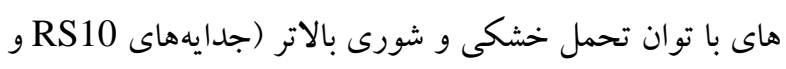

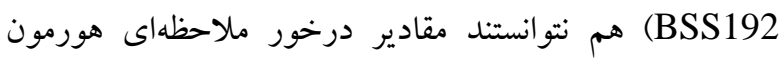

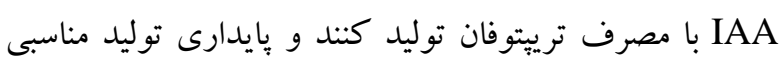
نسبت به جدايه RSS57 نداشتند. بهعبارت ديخر افزايش توليد

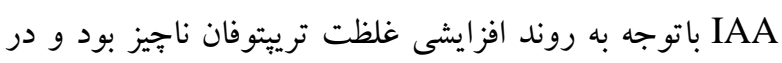

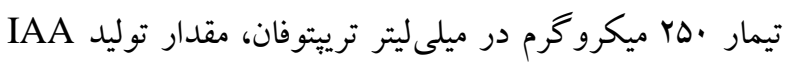

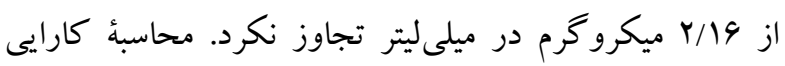

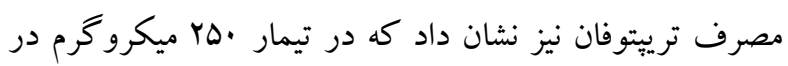

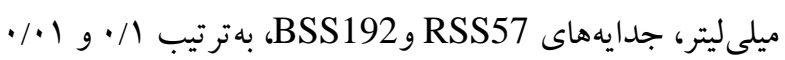

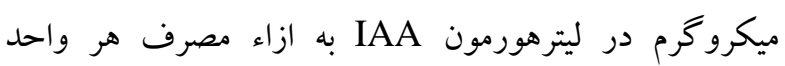

جدول F- تغييرات توليد هورمون IAA جدايههاى برتر در اثر مصرف مقادير مختلف ترييتوفان (با اعمال تنشهاى خشكى).

Table 4. IAA production variability of bacteria as affected by tryptophan treatments.

\begin{tabular}{|c|c|c|c|c|c|c|c|c|}
\hline \multirow[b]{2}{*}{ ميانگين } & \multicolumn{6}{|c|}{ غلظت ترييتوفان (ميكروگرم در ميلىليتر ) } & \multirow[t]{2}{*}{ 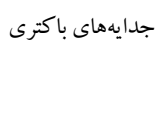 } & \multirow[t]{2}{*}{ رديف } \\
\hline & ro. & $r .$. & 10. & $1 \ldots$ & $\Delta$. & صفر & & \\
\hline$r / \Delta q B$ & $\Delta / r v a$ & $\Delta / \cdot 9 b$ & $F / F r b$ & $r / r \Delta c$ & r/rad & l/rd & RS11 & 1 \\
\hline$r / r v C$ & $r / r r b$ & $\Gamma / \backslash \wedge \mathrm{b}$ & $r / r b$ & r/FrC & $1 / 1 \mathrm{Vd}$ & l/rd & RN74 & r \\
\hline$\Delta / I F A$ & G/ADa & q/4qa & $9 / 1 \wedge \mathrm{a}$ & $\Delta / 91 \mathrm{a}$ & $F / r r b$ & $1 / \Delta \cdot d$ & RSS57 & $r$ \\
\hline $\mathrm{r} / 94 \mathrm{~B}$ & $\Delta / \cdot r b$ & $\mathrm{~F} / \mathrm{aqb}$ & $\mathrm{r} / 9 \mathrm{fb}$ & $r / 91 \mathrm{c}$ & $r / \cdot F d$ & $1 / 91 \mathrm{~d}$ & RSS32 & f \\
\hline$r / \cdot r C$ & $r / \Lambda \Delta b$ & r/99C & $\mathrm{r} / \mathrm{\Delta Vc}$ & $r / Y Q C$ & $1 / r F d$ & l/fe & $\mathrm{RS} 2$ & $\Delta$ \\
\hline $1 / N \mid D$ & r/Yac & r/TVC & r/TFC & r/YGC & $1 / \cdot 1 d$ & $\cdot / 1 \cdot d$ & RN65 & 4 \\
\hline r/FrC & $\Gamma / \backslash \wedge \mathrm{c}$ & $\Gamma / \Lambda \Delta C$ & $r / l \cdot c$ & $r / 9 \Delta c$ & $r / l \Delta d$ &.$/ \mathrm{rd}$ & RS10 & v \\
\hline r/qVC & $F / r k b$ & $F / r Y b$ & $r / r v c$ & $r / F \mid C$ & 1/9rd & $1 / \Delta \Delta d$ & BS153 & $\wedge$ \\
\hline$r / ৭ \Delta \mathrm{C}$ & $f / k r b$ & $F / r \& b$ & $r / r q c$ & $r / r q c$ & I/vAd & $1 / 4 \wedge d$ & BSS207 & 9 \\
\hline $1 / \Delta 1 \mathrm{D}$ & $\mathrm{r} / 19 \mathrm{~d}$ & $r / l \cdot d$ & $r / \cdot \Delta d$ & $r / \cdot 1 d$ & I/vad & I/fre & BSS192 & 1. \\
\hline
\end{tabular}

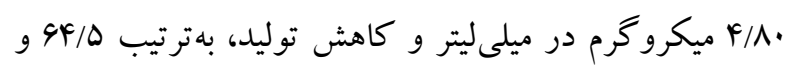
40/Y درصد بود (جدول ه). Ali و همكاران (2009) گزارش كردند كه در باكترىهاى جنس Pseudomonas با افزايش

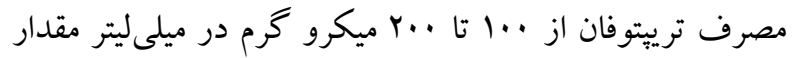

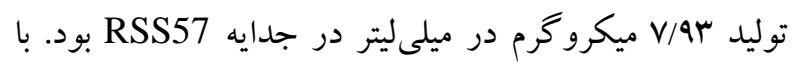
اعمال تنش ه- بار، توليد در اين جدايه به Q/ V/ ميكرو
در اين تحقيق، با ملاحظه اثر تنش خشكى و برهم كنش تنش خشكى و مصرف ترييتوفان، برترى جدايه RSS57 مشخص شد. بهنحوى كه علاوه بر اثر بذيرى كمتر از تنش خشكى در تنشهاى با شدت كم، در تنش نهايى (ه广- بار) نيز اين جدايه باكترى توانست به توليد خود ادامه دهد. درحالى كه در جدايههاى RS11 و RSS32، توليد هورمون IAA، بهترتيب F/AY و 


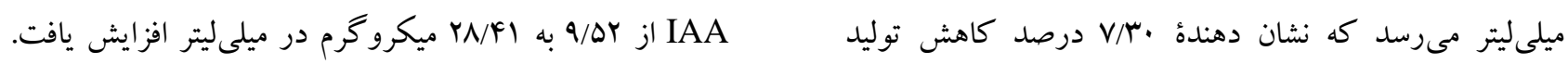

$$
\text { جدول ه- مقايسة تغييرات توليد هورمون IAA در سه جداية برتر، متأثر از برهم كنش مصرف ترييتوفان و تنش خشكى. }
$$

Table 5. Comparison of variability in IAA production of three upper isolates as affected by tryptophan and drought tension interaction.

\begin{tabular}{|c|c|c|c|c|c|c|c|}
\hline \multirow[b]{2}{*}{ ميانكين } & \multicolumn{6}{|c|}{ غلظت ترييتوفان (ميكرو گرم در ميلىليتر) } & \multirow[t]{2}{*}{ نتش خشكى (بار) } \\
\hline & ro. & $r \cdot \cdot$ & 10. & $1 \ldots$ & $\Delta$. & صفر & \\
\hline \multicolumn{8}{|c|}{ جدايه RSS57 } \\
\hline v/arA & $1 . / \mathrm{Ma}$ & $1 . \% \mathrm{ra}$ & ৭/৭८а & $\Lambda / V F b$ & $\Delta / a \& b$ & $r / . r d$ & . \\
\hline 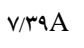 & $1 . / 1 \mathrm{ra}$ & $a / v \cdot a$ & $\Lambda / 9 \vee b$ & $V / \wedge a b$ & $\Delta / N r b$ & l/ard & $-\phi$ \\
\hline $9 \pi \mathrm{B}$ & $A * i b$ & $v / a \Delta b$ & $V / r \wedge b$ & g/NFC & $\Delta / 9 \wedge \mathrm{b}$ & I/vid & -1 \\
\hline$\Delta / \cdot \Delta C$ & $9 / \pi r b$ & $9 / 1+b$ & $91.4 b$ & $\Delta / \Delta q b$ & $F / \Delta \Delta c$ & $1 / 9 \wedge d$ & -10 \\
\hline$r / \Delta r D$ & $F / F \cdot c$ & $r / r \cdot c$ & $\mathrm{r} / \mathrm{rc}$ & r/A9d & r/A९d & $1 / 9 \Delta \mathrm{d}$ & $-r$. \\
\hline$\cdot N \cdot E$ & $\cdot / \mathrm{arc}$ & $\cdot / \wedge \Delta \mathrm{e}$ & $\cdot$ /vse & . vre & $\cdot / \Delta r e$ & $\cdot / 4 \cdot \mathrm{e}$ & $-r_{\Delta}$ \\
\hline \multicolumn{8}{|c|}{ جدايه RS11 } \\
\hline $9 / \Delta \Delta \mathrm{A}$ & $1 . / 49 \mathrm{a}$ & $1 . / 41 \mathrm{a}$ & $\Lambda / a r b$ & $F / r \cdot c$ & Y/AFd & I/Nrd & . \\
\hline $\mathrm{r} / \wedge \mathrm{rB}$ & $\mathrm{V} / \cdot \wedge \mathrm{b}$ & $V / r \wedge b$ & $\Delta / 9 \vee c$ & $F / \cdot A c$ & $r / a \& b$ & $1 / \Delta f d$ & $-\Delta$ \\
\hline$r / q / B$ & $9 / .9 \mathrm{~b}$ & $\Delta / 1 \Delta c$ & $F / Q / C$ & $r / \Delta \wedge C$ & r/A৭d & irye & -1 \\
\hline$r / r \cdot B$ & $F / \Delta q C$ & $r / 99 \mathrm{C}$ & $r / 99 \mathrm{c}$ & $r / l l c$ & $\mathrm{r} / 9 \mathrm{Vd}$ & 1/Me & -10 \\
\hline$r / \notin \varphi \mathrm{C}$ & $r / a \cdot d$ & $\mathrm{r} / \mathrm{AVd}$ & r/A৭d & $\mathrm{r} / \mathrm{DFd}$ & $r / 4 \cdot d$ & $1 / 1 \Delta \mathrm{e}$ & $-r$. \\
\hline$\cdots \mathrm{D}$ & \%..e & $\cdot / \cdot \mathrm{e}$ & $\%$ e & $\%$ e & $\% \mathrm{e}$ & ..e & $-r_{\Delta}$ \\
\hline \multicolumn{8}{|c|}{ جدايه RSS32 } \\
\hline g/rYA & $1 . / 49 a$ & $1 . / r v a$ & $\mathrm{~V} / \mathrm{rrb}$ & $F / \Delta \wedge C$ & $r / v \wedge d$ & $r / F \wedge \mathrm{d}$ & . \\
\hline$r / \Lambda \cdot B$ & $9 / 99 \mathrm{~b}$ & $9 / \mathrm{AFb}$ & $9 / 90 \mathrm{~b}$ & $F / F A C$ & $r / \Delta q d$ & l/A9d & $-\phi$ \\
\hline$F / B$ & $\Delta N \backslash b$ & $\Delta / N \backslash b$ & $\Delta / F \& b$ & $r / r \Delta c$ & $r / F \wedge d$ & l/Ald & -1 \\
\hline$r / r \Delta C$ & $r / A v b$ & $r / v \Delta c$ & $F / A F C$ & $r / r \cdot c$ & $r / r a d$ & I/Nve & -10 \\
\hline rNAC & $r / 19 \mathrm{c}$ & $r / l \cdot c$ & $r / 91 \mathrm{c}$ & $\mathrm{r} / 19 \mathrm{c}$ & $r / l \cdot d$ & I/Nrd & $-r$. \\
\hline$\cdot \cdot \mathrm{D}$ & . . e & $\cdot / . \cdot \mathrm{e}$ & $\%$ e & $\because \cdot \cdot \mathrm{e}$ & $\%$ e & $\cdot / \cdot \mathrm{e}$ & -ro \\
\hline
\end{tabular}

تنش در سطح EC برابر با ها دسىزيمنس بر متر ) روى هم قرار

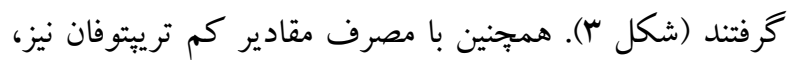
اين جدايه برتر توانست مقادير نسبى قابل ملاحظهاى از هورمون

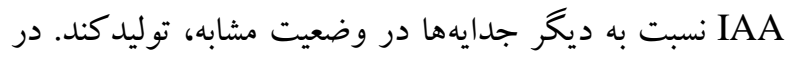

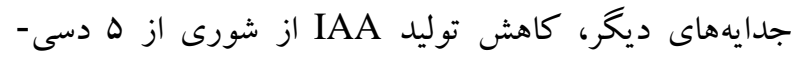
زيمنس برمتر شروع شده و اين موضوع در شكل لَ با مشاهده فاصله ايجادشده منحنىهاى تنش شورى، نسبت به منحنى بدون تنش شورى (شاهد) مشخص مىشود.
اثر مصرف توييتوفان و سطوح تنش شورى بر توليد

هورمون IAA

بررسى تغييرات توليد هورمون IAA در اثر برهم كنش تنش

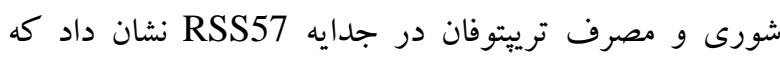
مقدار شورى برابر با ها دسىزيمنس برمتر نسبت به شرايط بدون

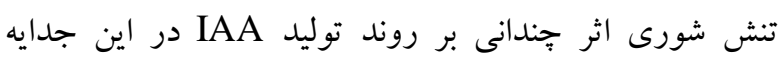
نداشت بهطورى كه منحنى حاصل از هر دو حالت (بدون تنش و 

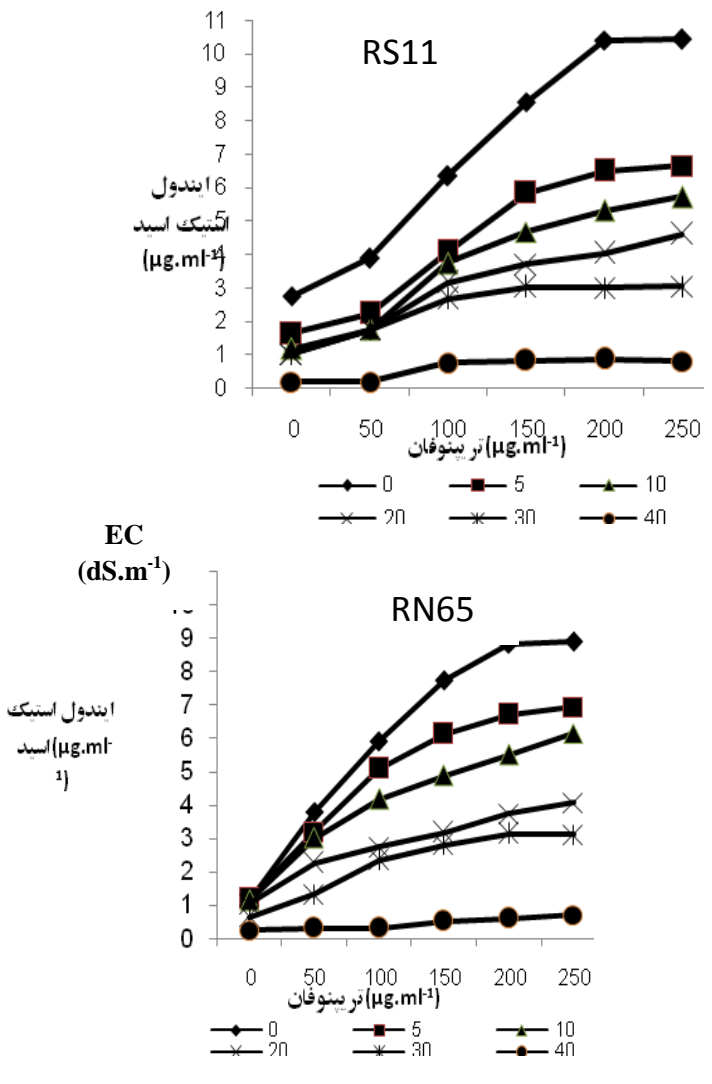

EC

(dS.m $\left.{ }^{-1}\right)$
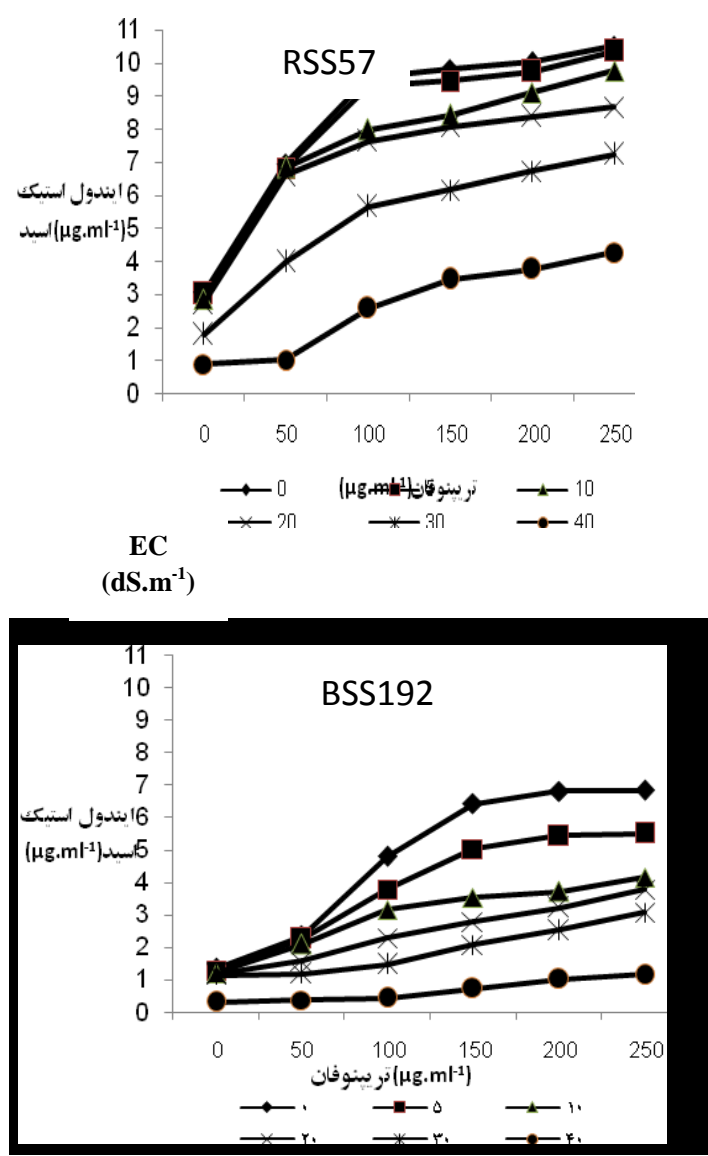

EC

$\left(\right.$ dS.m $\left.^{-1}\right)$

شكل ץ- روند تغييرات توليد هورمون IAA توسط \& جدائ برتر در سطوح مختلف ترييتوفان و تنش شورى .

Fig. 3. The trend of variability in IAA production by 4 upper isolates at different levels of tryptophan and salinity tension.

سلولهاى مرده جانداران خاكى در ريزوسفر نسبت به توده خاكك، فراوانى و مقدار توليد هورمون IAA در باكترىهاى جداشده از ريزوسفر بيشتر بود.

در وضعيت تنشهاى خشكى، شورى و شور-سديمى، ترشحات ريشهاى به تبعيت از رشد گياه، كمتر بود و تريّتوفان كمترى در اختيار باكترىها قرار مى گرفت (Ahmed et al., 2008). از طرفى، جمعيت باكترىها و تودههاى مرده آنها، كمتر بود و منبع تريبتوفان فراوانى در دسترس باكترى قرار نمى گرفت. بنابراين كارايى بيشتر مصرف ترييتوفان در اين شرايط، تعيين كنندهُ موثر بودن تلقيح بوده و بهتدريج با افزايش ريشههاى كياه، اثر متقابل

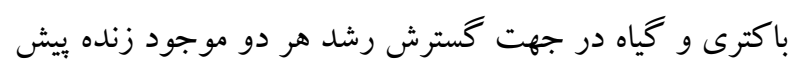
مىرفت. Swain و همكاران (2007) كزارش كردند كه
در اين تحقيق، باتوجه به اين كه نمونهبردارى اوليه به تعداد زياد و از خاككهاى با درجات مختلف EC و SRA انجام شد، باكترىهاى جداسازىشده نيز به همان نسبت، متنوع بودند و توانايى هاى متفاوتى در توليد هورمون IAA در شرايط تنشهاى خشكى و شورى و كارايىهاى مختلفى نسبت به مصرف ترييتوفان از خود نشان دادند. Dilfuza (2011) گزارش كرد كه •ه درصد از باكترىهاى جداسازىشده از ريزوسفر، قادر به توليد هورمون IAA بودند. باتوجه به تجزيه و تحليل نمودارهاى فراوانى، مشخص شد كه توانايى توليد هورمون IAA در سطوح بالا، در باكترىهاى جداسازىشده از ريزوسفر كندم نسبت به باكترىهاى جداسازى شده از تودهُ خاكك بيشتر بود. به نظر مى رسد كه بهدليل وجود تركيباتى مانند هيدراتهاى كربن و تركيبات آلى در ترشحات ريشهاى اطراف ريشه و همجنين 
كننده از خشكى از جمله ترهالوز و گكلوتامين است و همين

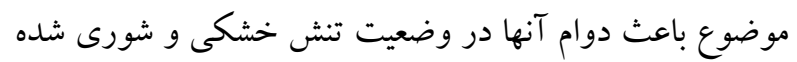
است. هرجند در مورد A. siccitolerans گزارشى از توليد

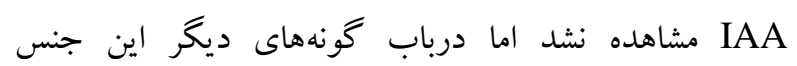
تحقيقاتى انجام شده است. Banerjee و همكاران (2010)

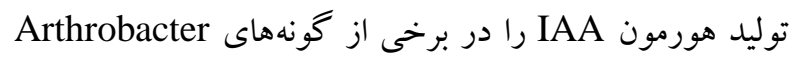

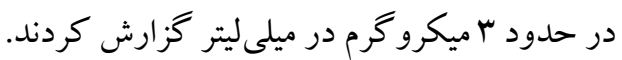

\section{نتيجه كيرى}

باستفاده از جندين مرحله آزمون و مقايسٔ جدايهها، يكك باكترى متعلق به گونه

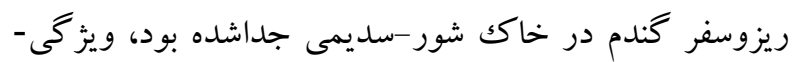
هاى باكترى برتر را داشت. بهطورى كه محاسبة كارايى مصرف

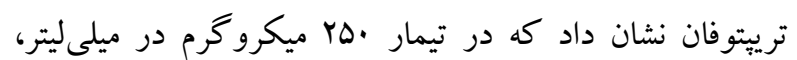

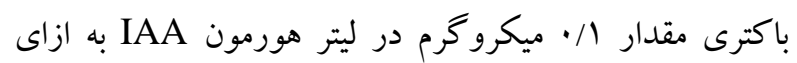

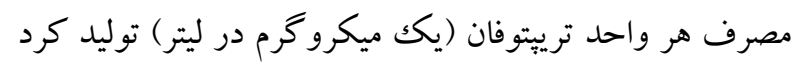

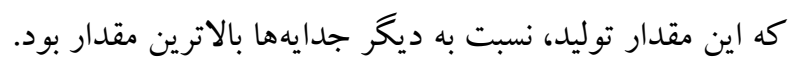

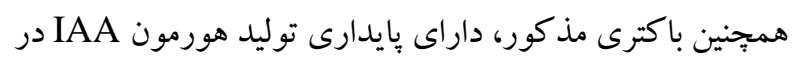

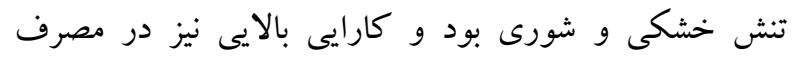

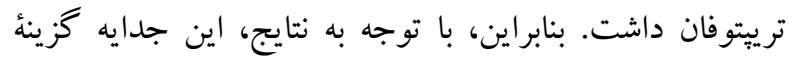

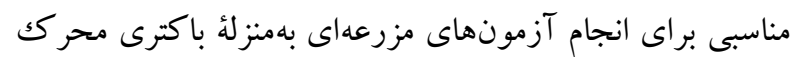

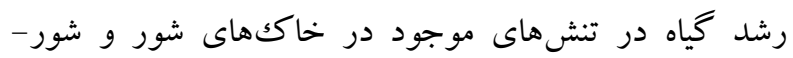

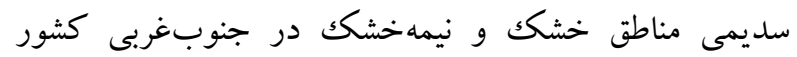
محسوب مىشود و مىتواند به توسعه رشد ريشه، جذب بيشتر

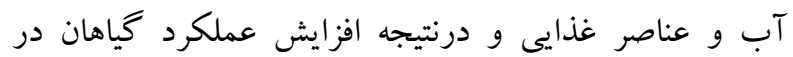
اوضاع دشوار محيطى كمك كند.

\section{References}

Ahmed, R., Khalid, A., Arshad, M., Zahir, Z.A., and Mahmood, T. 2008. Effect of compost enriched with N and L-tryptophan on soil and maize. - Agronomy Sustainable Development 28: 299-305.

Ali, B., Sabri, A.N., Ljung, K., and Hasnain. 2009. Auxin production by plant associated bacteria: impact on endogenous IAA content and growth of Triticum
باكترى Bacillus subtilis، مقادير متغيرى از هورمون IAA (كمان

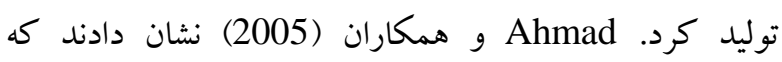
تعدادى از جدايههاى Pseudomonas flurescens قادر بودند

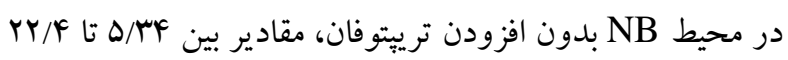
ميكرو گرم در ميلىليتر IAA توليد كنند. همجنين، باكترى RSS57 در وضعيت تنشهاى خشكى و شورى، بيشتر از ديخر ميكر دئر

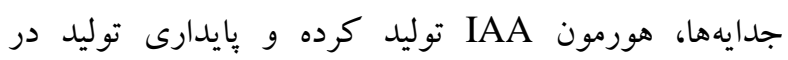
بتانسيل هاى اسمزى مختلف و مقادير شورى كم تا زياد را از

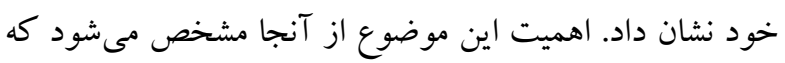
محققين مختلف ازجمله Berg و همكاران (2013) اظهار

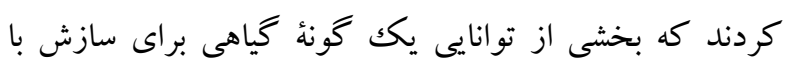

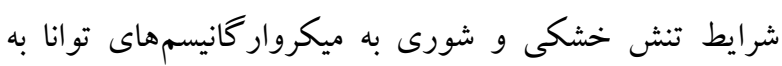

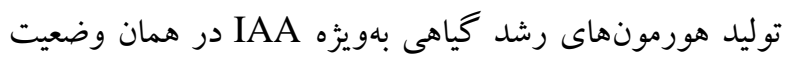

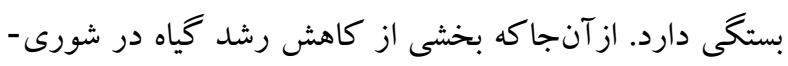

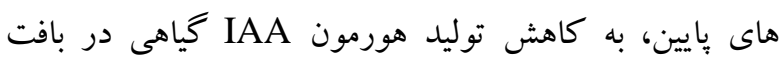

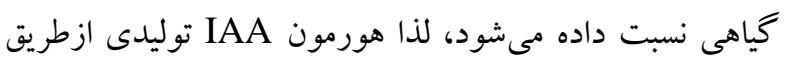

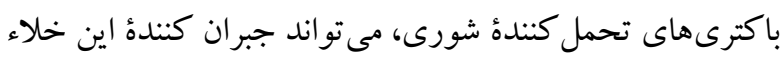
در گياه باشد (Alqarawi, et al., 2014).

\section{نتيجه شناسايع جدايؤ باكترى بوتر}

بساز انجام مراحل شناسايى زنتيكى، نتايج تعيين توالىها، در

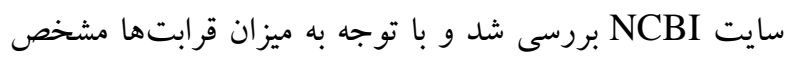

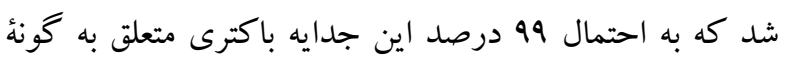
Narvaez- مى Arthrobacter siccitolerans Narvaez-Reinaldo باكترىهاى جنس Arthrobacter، كه از ريزوسفر گياهان مناطق خشك جداسازى شد، تجمعدهندة تركيبات محافظت-

aestivum L. - Letters in Applied Microbiology 48: 542-547.

Alqarawi, A.A., Abd Allah, E.F., Hashem, A., Al Huqail, A., Asma, Abdulaziz, A. and Al-Sahli A.A. 2014. Impact of abiotic salt stress on some metabolic activities of Ephedra alata Decne. - Journal of Food, Agriculture and Environment 12: 620-625. 
Banerjee, S., Palti, R., Sengupta, C., and Standing, D. 2010. Stress induced phosphate solubilization by Arthrobacter sp. and Bacillus sp. isolated from tomato rhizosphere. - Australian Journal of Crop Science 4: 378-383.

Bent, E., Tuzan, S., Chanway, C.P. and Enebak, S. 2001. Alteration in plant growth andin root hormone levels of lodgepole pines inoculated with rhizobacteria. - Canadian Journal of Microbiology 47:793-800.

Berg, G., Alavi, M., Schmidt, C.S., Zachow, C., Egamberdieva, D. and Lugtenberg, F.B. 2013. Biocontrol and osmoprotection for plants under saline conditions. In: J. de Bruijn Frans (Ed.), Molecular Microbial Ecology of the Rhizosphere. - WileyBlackwell, USA.

Dauphin, L., Moser, A. and Bowen, M.D. 2009. Evaluation of five commercial nucleic acid extraction kits for their ability to inactivate Bacillus anthracis spores and comparison of DNA yields fom spores and spiked environmental samples. - Journal of Microbiology Methods 76:30-37.

Dilfuza, E. 2011. Indole-acetic acid production by root associated bacteria and its role in plant growth and development. In: Keller, A.H., and Fallon, M.D. (Ed.), Auxins: Structure, Biosynthesis and functions. - Nova Science Publishers, Inc.

Fernandez-Falcon, M., Borges, A. and Borges-Perez, A. 2003. Induced resstance to Fusarium wilt of banana by exogenous applications of indoleacetic acid. Phytoprotection 84:149-153.

Lamine, B., Maria, L.V. and Marc-Andre, F. 2008. Induction and growth of hairy roots for the production of medicinal compounds. - Electronic Journal of Integrative Bioscience 3:1-9.

Lorraine, G.W., D.L. Balkwill, F.H. Crocker, B.N. Bjornstad, and Robert, V.M. 2000. Genetic diversity among Arthrobacter Species collected across a heterogeneous series of terrestrial deep-subsurface sediments as determined on the basis of 16S rRNA and recA gene sequences. - Applied Environmental Microbiology 66: 3454-3463.

Kavamura, V.N., Santos, S.N., and Melo, I.S. 2013. Screening of Brazilian cacti rhizobacteria for plant growth promotion under drought. - Microbiological Research 168: 183-191.

Maciel, B.M., Santos, A.C.F., Dias, J.C.T., Vidal, R.O., Dias, R.G.C., Gross, E., Cascardo, J.C.M. and Rezende, R.P. 2009. Simple DNA extraction protocol for a $16 \mathrm{~S}$ rDNA study of bacterial diversity in tropical landfarm soil used for bioremediation of oil waste. Genetics and Molecules Research 8: 375-388.

Mandal, S.M., Mondal, K.C., Dey, S. and Pati, B.R. 2007. Optimization of cultural and nutritional conditions for indole-3-acetic acid (IAA) production by a Rhizobium sp. isolated from root nodules of Vigna mungo (L.) Hepper. - Research Journal of Microbiology 2: 239-246.

Mangang, J.S., Deaker, R. and Rogers, G. 2015. Early seedling growth response of lettuce, tomato and cucumber to Azospirillum brasilense inoculated by soaking and drenching. - Horticultural Science 42: 3746.

Matsukawa, E., Nakagawa, Y., Iimura, Y. and Hayakawa, M. 2007. Stimulatory effect of indole-3acetic acid on aerial mycelium formation and antibiotic production in Streptomyces spp. Actinomycetologica 21: 32-39.

Michel, B.E. and Kaufmann, M.R. 1973. The osmotic potential of polyethylene glycol 6000. - Plant Physiology 51:914-916.

Mohite, B. 2013. Isolation and characterization of indole acetic acid (IAA) producing bacteria from rhizospheric soil and its effect on plant growth. Journal of Soil Science and Plant Nutrition 13: 638649.

Narváez-Reinaldo, J.J., Barba, I., González-López, J., Tunnacliffe, A. and Manzanera, M. 2010. Rapid method for isolation of desiccation-tolerant strains and xeroprotectants. - Applied Environmental Microbiology 76: 5254-5262.

Page, A.L., Miller, R.H. and Keeney, D.R. 1982. Methods of Soil Analysis. 2nd Edn. - American Society of Agronomy, Madison, WI., USA.

Patten, C.L. and Glick, B.R. 2002. Role of pseudomonas putida indoleacetic acid in development of host plant root system. - Applied Environmental Microbiology 68: 3795-3801.

Sandhya, V., Ali S.K.Z., Minakshi, G., Reddy, G. and Venkateswarlu, B. 2009. Alleviation of drought stress effects in sunflower seedlings by the exopolysaccharides producing Pseudomonas putida strain GAP-P45. - Biology and Fertility of Soils 46: $17-26$.

Spaepen, S., Vanderleyden, J. and Remans, R. 2007. Indole-3-acetic acid in microbial and microorganismplant signaling. - FEMS Microbiological Review 31:425-448.

Spaepen, S. and Vanderleyden, J. 2012. Auxin and plant-microbe interactions. - Cold Spring Herbal Perspect Biology 10: 1-14.

Swain, M.R., Naskar, S.K. and Ray, R.C. 2007. Indole3-acetic acid production and effect on sproutingof yam. (Dioscorea rotundata L) Minisetts by Bacillus subtilis isolated from culturable cowdungmicroflora. - Polish Journal of Microbiology 56: 103-110. 
Wang, Q.F., Li, W., Liu, Y.L., Cao, H., Li, Z. and Guo, G.Q. 2007. Bacillus qingdaonensis sp. nov., a moderately haloalkaliphilic bacterium isolated from a crude sea-salt sample collected near Qingdao in eastern China. - International Journal of Systematic Evolution in Microbiology 57: 1143-1147.
Woodward, A.W. and Bartel, B. 2005. Auxin: regulation, action, and interaction. - Annuals of Botany 95: 707-730.

Soleimani, R., Tofighi, H. and Alikhani, H. 2015. The effect of drought and salinity tensions on IAA production in isolated bacteria from saline and saline-sodic soils. - Nova Biologica Reperta 2: 186-198.

سليمانى، ر.، توفيقى، ح. و عليخانى، ح.ع. عqזا. اثر تنشهاى خشكى و شورى بر توليد هورمون IAA در باكترىهاى جداسازى شده از خاككهاى شور و شور سديمى.- يافتهاى نوين در علوم زيستى ب: 191-114. 